\title{
FULGORA LANTERNARIA.
}

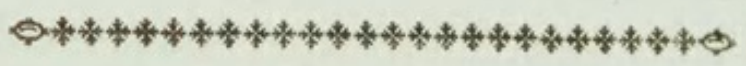

\section{CHARACTER GENERICUS.}

Caput fronte producta, inani.

Antennce infra oculos: articulis 2; exteriore globofo majore.

Roftrum inflexum.

$P$ edes grefforii.

$$
\text { Lin. Syft. Nat. p. } 703 \text {. }
$$

CHARACTER SPECIFICUS, EंC.

FULGORA fronte ovali recta, alis lividis; pofticis ocellatis.

$$
\text { Lin. Syf. Nat. p. } 703 \text {. }
$$

\section{LANTERNARIA.}

Mex.. Sur. t. 49.

Röfel. InS. 2. gryll. t. 28, 29.

Fabr. Spec. Inf. vol. 2. p. $3^{13}$.

Vix aliud in Infectis videtur mirabilius luce illa phofphorea, quam certæ fpecies emittunt. Inter infecta Europæa, Lampyrides, (quæ ad Coleoptera Linnæi referuntur) maxime hac qualitate pollent. In America eft fpecies Elateris, cui multa ineft vis lucem in tenebris fpargendi. Scolopendra etiam vulgaris Europæa, (qua Scolopendra electrica Linnæi) manifefte noctu 
lucet, præfertim fi aliquo modo fit irritata aut compreffa. Præ cæteris tamen infectis eminet fpecies in tabula depicta, quæ communiter Lanternaria Peruviana dicitur: lucem enim adeo vividam fpargit, ut viatores noctu ambulantes iter fuum commode peragere poffint, ope unius vel duorum horum animalium, baculo alligatorum, geftatorumque more facis. Infectum hoc ad ordinem naturalem pertinet infectorum quatuor alas habentium, quarum exteriores funt magis coriaceæ feu denfæ in parte fuperiore quam inferiore. Hujus ordinis infecta Hemiptera Linnæi conftituunt, inter quæ major pars roftrum tubulatum fub pectore gerunt, cujus ope fugendo fe nutriunt. Hinc patet Fulgoram et Cicadam effe valde affines. Fulgora frequens in America calidiori reperitur, et a Domina Merian in hiftoria fua infectorum Surinamenfium nec non ab aliis Naturæ indagatoribus defcripta eft. Non injucunde narrat Merian metum fibi ingentem incuffiffe flammeas corrufcationes ab infectis hifce exortas, cum adhuc facultatis quam habent lucem in tenebris emittendi ignara effet. "Cum aliquando (inquit illa) Lanternarios magna copia mihi attuliffent Indi, fcatulæ eofdem majori lignea inclufi, illos noctu lucere adhuc infcia; verum de nocte infolito ftrepitu expergefacta, et perterrita, e lecto profiliens, lumen accendere juffi, quis domi meæ infuetus effet ftrepitus ignara. Tum vero e fcatula ftridorem profectum illico nobis patuit; illam itaque cum animi quadam perturbatione aperuimus, fed adapertam magis adhuc paventes in terram fubito dejecimus, quod inter aperiendum inde velut ignea erumperet flamma, toties refulgens quoties novum evolaret 
evolaret infectum: quo tandem animadverfo, ad nos redeuntes, iterum congregavimus animalcula, fplendorem in ipfis plurimum demiratæ." Ope etiam unius infecti, ut affirmat Merian commode aliquis noctu legere poteft.

Non abs re fit addere quod quamvis Domina Merian figuras horum animalium pulchre et accurate depingi curaverit, tamen transformationem ipfius infecti a larva ad integrum ftatum defcribere conata, figuram, ut videtur, fictam introduxit, nempe cicadæ fpeciem (quæ Cicada Tibicen Linnæi) cum capite Fulgoræ.

Lux phofphorea a Fulgora dimanans, a capite concavo feu velut inflato procedit: nulla enim alia pars phofphorea eft. 


\section{GREAT LANTHORN-FLY, \\ O R \\ F I R E - F L Y.}

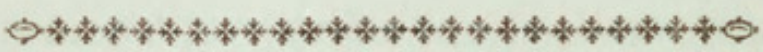

GENERIC CHARACTER.

Head hollow, inflated, and produced forwards. Antenna below the eyes, confinting of 2 joints, the exterior larger and globofe.

Beak inflected.

Feet formed for walking.

SPECIFIC CHARACTER, EंC.

FULGORA with large oval head; variegated wings; the lower pair ocellated.

LANTERNARIA.

Merian. Sur. t. 49 .

Röfel. vol. 2. t. 28,29 .

Few circumftances are more remarkable amongft infects than the phofphoric light with which fome particular fpecies abound. Amongft the European infects this quality is moft confpicuous in the Glow-Worms, which are of the Linnæan genus Lampyris, and belong to the Coleopterous tribe. In America a large fpecies of Elater, or Springing-Beetle is poffeffed of this faculty 


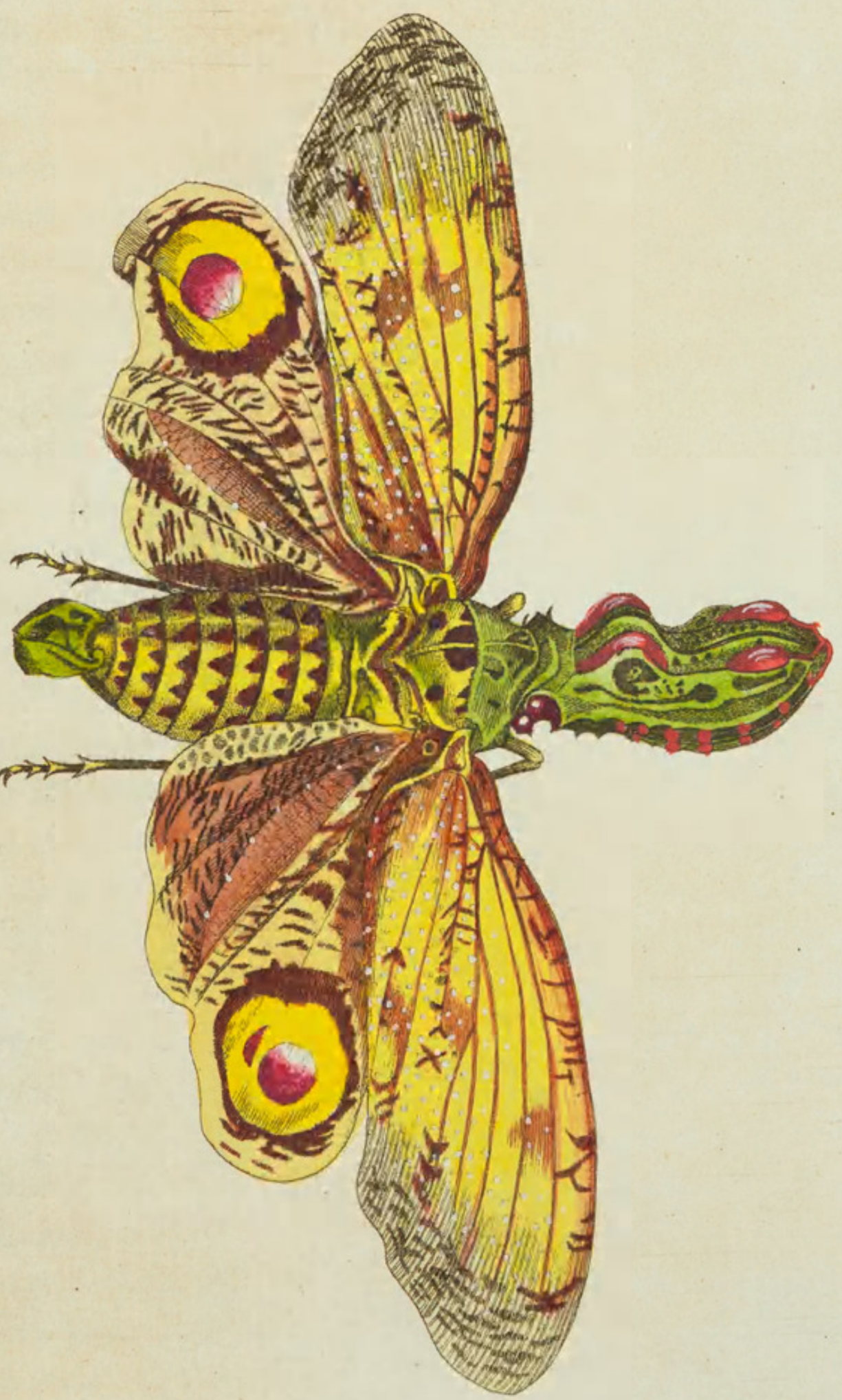



in a very high degree; the common fmall Scolopendra of Europe, and which is well known in our own country, is pretty ftrongly phofphoric likewife, efpecially if preffed or irritated; but of all infeets that which is here reprefented, and which is generally called the Lanthorn-Fly of Peru, poffeffes this lucid quality in the moft eminent degree, and affords a light fo vivid, that travellers walking by night are faid to be enabled to purfue their journey with fufficient certainty by one or two of thefe infects tied to a ftick and carried in the manner of a torch. The infect belongs to the natural order of Hemipterous infects, or fuch as are furnifhed with four wings, of which the exterior pair on the upper part are of a ftronger or more coriaceous nature than on the lower. The divifion in this tribe to which it ftrictly belongs, is that containing the roftrated infects, or fuch as have a tube or inftrument of fuction lying flat, beneath the breaft. It is therefore extremely nearly allied to the genus Cicada. It is common in many parts of South America, and amongft other writers is defcribed by the celebrated Madam Merian in her hiftory of the Surinam infects. She gives an entertaining account of the alarm into which the was thrown by the flafhing which proceeded from them in the dark, before the had been apprized of their fhining nature.

"The Indians once brought me (fays the) before I knew that they thone by night, a number of thefe Lanthorn-Flies, which I fhut up in a large wooden box. In the night they made fuch a noife that I awoke in a fright, and ordered a light to be brought, not being able to guefs from whence the noife proceeded: 
as foon as we found that it came from the box, we opened it, but were alarmed ftill much more, and let it fall to the ground in a fright at feeing a flame of fire come out of it; and as many animals as came out, fo many flames of fire appeared. When we found this to be the cafe, we recovered from our fright, and again collected the infects, much admiring their fplendid appearance." She adds, that the light of one of thefe infects is fo vivid that a perfon may fee to read a newspaper by it.

It may not be improper to obferve, that though Madam Merian has given good figures of the Fire-Fly, yet, by way of explaining the change from its fuppofed larva into the complete infect, fhe feems to have introduced an imaginary figure, reprefenting the Cicada Tibicen with the head of a Fulgora. The light emitted by the Fire-Fly proceeds entirely from the hollow part, or Lantern of the head; no other part of the animal being luminous. 


\section{$2 \mathrm{BHL}$ Biodiversity Heritage Library}

Shaw, George. 1790. "The Great Lanthorn-Fly or Fire-Fly, Fulgora lanternaria [PI. 37]." The Naturalist's Miscellany 1(XII), https://doi.org/10.5962/p.310689.

View This Item Online: https://www.biodiversitylibrary.org/item/281460

DOI: https://doi.org/10.5962/p.310689

Permalink: https://www.biodiversitylibrary.org/partpdf/310689

\section{Holding Institution}

Museums Victoria

\section{Sponsored by}

Atlas of Living Australia

\section{Copyright \& Reuse}

Copyright Status: Public domain. The BHL considers that this work is no longer under copyright protection.

This document was created from content at the Biodiversity Heritage Library, the world's largest open access digital library for biodiversity literature and archives. Visit BHL at https://www.biodiversitylibrary.org. 